\title{
Fossil seeds from the La Cantera Formation, Early Cretaceous, San Luis Province, Argentina
}

\author{
MARÍA A. GÓMEZ1* ${ }^{*}$ GABRIELA G. PUEBLA², MERCEDES B. PRÁMPARO² \\ and ANDREA B. ARCUCCI ${ }^{3}$ \\ ${ }^{1}$ IMIBIO-CONICET - San Luis. Facultad de Química, Bioquímica y Farmacia, Universidad Nacional de San \\ Luis, Ejercito de los Andes 950, San Luis (5700), Argentina; e-mail: gomezmarian80@gmail.com \\ ${ }^{2}$ Instituto Argentino de Nivología, Glaciología y Ciencias Ambientales, Centro Científico Tecnológico - \\ CONICET y UNCuyo. Av. Adrián Ruiz Leal s/n - Mendoza C.C.131 (5500), Argentina; \\ e-mails: gpuebla@mendoza-conicet.gob.ar, mprampar@mendoza-conicet.gob.ar \\ ${ }^{3}$ Facultad de Química, Bioquímica y Farmacia, IMIBIO - Universidad Nacional de San Luis, Chacabuco 913, \\ San Luis (5700), Argentina; e-mail: andrea.arcucci@gmail.com
}

Received 21 November 2019; accepted for publication 6 June 2020

\begin{abstract}
In a study of fossil seeds recovered from the La Cantera Formation, Early Cretaceous, San Luis Basin, we establish a new species, Carpolithus volantus, and describe other specimens attributed to Carpolithus spp. and Ephedra canterata. The botanical affinity of winged seeds assigned to Carpolithus volantus is discussed in relation to the fossil flora recovered from this formation. Based on the abundance of Gnetales in the San Luis Basin (pollen grains, reproductive and vegetative structures assigned to Ephedra), we propose that Carpolithus volantus is affiliated with Gnetales (Weltwitschia). We suggest that Carpolithus spp. seeds may be angiospermous, because this group, represented by leaves and flowers, dominates the fossil macroflora of the La Cantera Formation. Micro- and macrofloral analyses of the La Cantera Formation and an assessment of available dispersal vectors suggests that wind (anemochory) and water (hydrochory) may have been the most important dispersal strategies for these seeds. The abundance and small size of seeds recovered from the La Cantera Formation, together with their morphological characters, such as the presence of wings in Carpolithus volantus, also favour abiotic mechanisms of dispersal such as anemochory or hydrochory.
\end{abstract}

KEYWORDS: Fossil seeds, Carpolithus, La Cantera Formation, Early Cretaceous, Central-western Argentina

\section{INTRODUCTION}

Study of reproductive structures is crucial to an understanding of the life cycle of plants; moreover, morphological variations commonly reflect ecological and environmental adaptations (Harper et al., 1970; Haig and Westoby, 1989; Westoby et al., 2002; Tiffney, 2004; Sims, 2012). Seed anatomy contributes to accurate identification of whole-plant taxa (e.g., Vaughan, 1970; Wu et al., 2014; Benedict et al., 2015, 2016; McLoughlin and Pott, 2019), but research on fossil seeds presents many difficulties related to intra- and interspecific variability, as well

Corresponding author as morphologies that might alternatively be related to phylogeny or environmental conditions (Harper et al., 1970; Archangelsky, 2000). The great diversity of seed shape and size is related in part to seed dispersal mechanisms (Eriksson et al., 2000; Moles et al., 2005a,b; Eriksson, 2008; McLoughlin and Pott, 2019), so seeds offer a good starting point for interpreting plant palaeoecology (Tiffney, 1984; McLoughlin and Pott, 2019). The most primitive fossil seeds lack obvious adaptations to specific dispersal vectors (e.g., wind, water, animals) (Moles et al., 2005a), but wind and water probably have been the primary seed dispersal vectors 
since the emergence of terrestrial plants. From the Middle Jurassic to the Early Cretaceous, anemochory was a key strategy for seed dispersal (McLoughlin and Pott, 2019). Numerous fossil fruits and seeds have been described from the Cretaceous, many with excellent anatomical details preserved (Friis et al., 2011). Discussions about their dispersal mechanisms are rare. The most complete Early Cretaceous floras studied, including flowers, fruits, seeds and pollen grains, come from the Potomac Group at the Kenilworth and Puddledock localities, eastern North America (Crane et al., 1993; Pedersen et al., 1994; Friis et al., 2009), the non-marine Wealden Group of southern England (Austen and Batten, 2018), various localities in Portugal (Buarcos, Catefica, Torres Vedras: Lugar d' Almen, Fonte Granda and Almargem formations), and Famalicão (Figueira da Foz Formation) in the Lusitanian Basin (Friis et al., 1999, 2009). Other well-studied floras of this age come from the Jehol Group (Sunjiawan, Fuxin, Jiufotang, Yixian, Zhangjiakou and Tuchengzi formations) in Liaoning Province, China (Chang et al., 2003; Sha, 2007; Wang et al., 2016), and the Koonwarra Fossil Bed (Eumeralla Formation), Australia (Drinnan and Chambers, 1986; McLoughlin and Pott, 2019).

From Argentina there are records of Carpolithus in the Piedra Clavada Formation (Early Cretaceous), Quebrada Don Nielsen locality, Santa Cruz Province (Ballent et al., 2011). Seed compressions of angiosperms were described by Frenguelli (1953) from the Mata Amarilla Formation (Late Cretaceous), Santa Cruz Province.

Most Late Cretaceous records in this region come from Patagonia. For example, Gandolfo and Cúneo (2005) described fruit compressions with seeds similar to Nelumbo Adans (Nelumbonaceae) from the La Colonia Formation, Chubut Province. From the Neuquén Basin, seeds and angiospermoid reproductive structures from the Portezuelo Formation, Neuquén Group, have been assigned to two species of Carpolithus (Passalía et al., 2008).

Seed cuticles provide other evidence of the presence of reproductive structures in the fossil record. Most seed cuticles from the Cretaceous are assigned to the fossil genera Costatheca and Spermatites, both of uncertain botanical affinity. These "mesofossils", with dimensions of $0.28-2.50 \mathrm{~mm}$, possibly are related to either angiosperms or gymnosperms, but the chance that some of them are insect eggs cannot be dismissed (Batten and Zavattieri, 1995, 1996). In Argentina, seed cuticles assigned to Spermatites were mentioned from the Plottier Formation (Late Cretaceous) Neuquén Group, (Musacchio and Vallati, 2007), and Costatheca was recorded from the Loncoche Formation (Late Cretaceous) at the Calmu-Co section (Papú, 2002), both from southern Mendoza.

The La Cantera Formation (El Gigante Group) has provided one of the most diverse and complete associations of palynomorphs and plant macrofossils from the late Aptian of central western Argentina, including primitive angiosperms (Prámparo, 1990, 1994; Prámparo et al., 2007; Archangelsky et al., 2009; Puebla, 2009, 2010; Puebla et al., 2012, 2017). In addition, reproductive structures including several fossil seeds of different morphological types were identified. Before the present study, these fossil seeds were not described in detail, except for ovulate cones of $E$. canterata published recently by Puebla et al. (2017). Here we provide new photos and descriptions of more specimens of this species. We describe and provide details of the reproductive structures recovered from the La Cantera Formation, San Luis Basin. We discuss their botanical affinities and propose possible forms of dispersal, based on seed morphology. Finally, considering the entire group of plants represented in the fossil record of the basin, we evaluate their possible dispersal strategies and their implications for paleoecological and paleoenvironmental interpretation of mid-latitude Cretaceous floras of central western Argentina, South America.

\section{GEOLOGICAL SETTING}

The studied fossils come from the type section of the La Cantera Formation $\left(32^{\circ} 59^{\prime} 25^{\prime \prime} \mathrm{S}\right.$, $66^{\circ} 52^{\prime} 48^{\prime \prime} \mathrm{W}$ ) of the El Gigante Group (Flores and Criado Roque, 1972), San Luis Basin, Argentina (Fig. 1). The El Gigante Group consists of six formations: Los Riscos, El Jume, La Cantera, El Toscal, La Cruz and Lagarcito (Flores, 1969; Rivarola and Spalleti, 2006).

The La Cantera Formation is built of laminated greenish grey mudstone, siltstone and claystone, with reddish brown sandstone and grey siltstone interbedded at the top of the succession. It may represent deposition in ephemeral lakes related to a fluvial environment with some periods of a very quiet lacustrine system 
allowing the preservation of delicate fossils (Flores and Criado Roque, 1972; Criado Roque et al., 1981; Prámparo, 1989). Recently, Castillo-Elías et al. (2016) described MISS structures related to a bacterial seal (biofilms), which probably protected the organisms from degradation, making the La Cantera Formation an important source of paleoecological and paleoenvironmental information on a Cretaceous siliciclastic lacustrine system. Prámparo (1999a) interpreted the formation to have been deposited in a shallow freshwater eutrophic environment with some evaporitic episodes, based on the presence of a diverse and abundant phytoplankton (Scenedesmus, Tetrastrum, Tetraedron, Botryococcus, Leiosphaeridia) (Tab. 1). Aquatic insects, fish, ostracods and spinicaudatans have been recorded in the same sections (Petrulevicius et al., 2010; Arcucci et al., 2015; Giordano, 2017). Based on palynological studies, the La Cantera Formation is late Aptian in age (Prámparo, 1990, 1994, 1999a,b; Prámparo et al., 2007).

\section{MATERIAL AND METHODS}

The described specimens were found in finely laminated shales as coalified compressions lacking preserved cuticles. A total of 64 reproductive structures were studied and compared with published Cretaceous seeds (e.g., Tiffney, 1984; Friis et al., 2014). Modern comparative material was obtained from the collections of Herbario de Plantas Vasculares del Museo de Ciencias Naturales "Bernardino Rivadavia", Buenos Aires, Argentina (BA).

The fossils were studied using a Leica Mz 125 stereomicroscope and photographed with a Nikon Coolpix 990 digital camera. Some specimens were observed using a LEO 1450VP scanning electron microscope (SEM) of LABMEM (Laboratorio de Microscopía Electrónica y Microanálisis, Universidad Nacional de San Luis). Fossil specimens are housed at Museo Interactivo de Ciencias (MIC) of Universidad Nacional de San Luis (UNSL), San Luis Province, Argentina, under the acronym MIC-P.

\section{COMPOSITION OF THE FOSSIL FLORA}

The fossil record of La Cantera comprises impressions and compressions of bryophytes, monilophytes (Equisetidae), gnetophytes (Ephe$d r a$ ), angiosperms, and various reproductive structures such as seeds, cones and flowers (Puebla, 2009, 2010; Puebla et al., 2012, 2017) (Tab. 1). The palynoflora was dominated in nearly all the studied assemblages by aquatic forms such as freshwater algae (Prámparo, $1988 b, 1990,1994,2012)$. The terrestrial paleoflora was dominated by gymnosperms, with

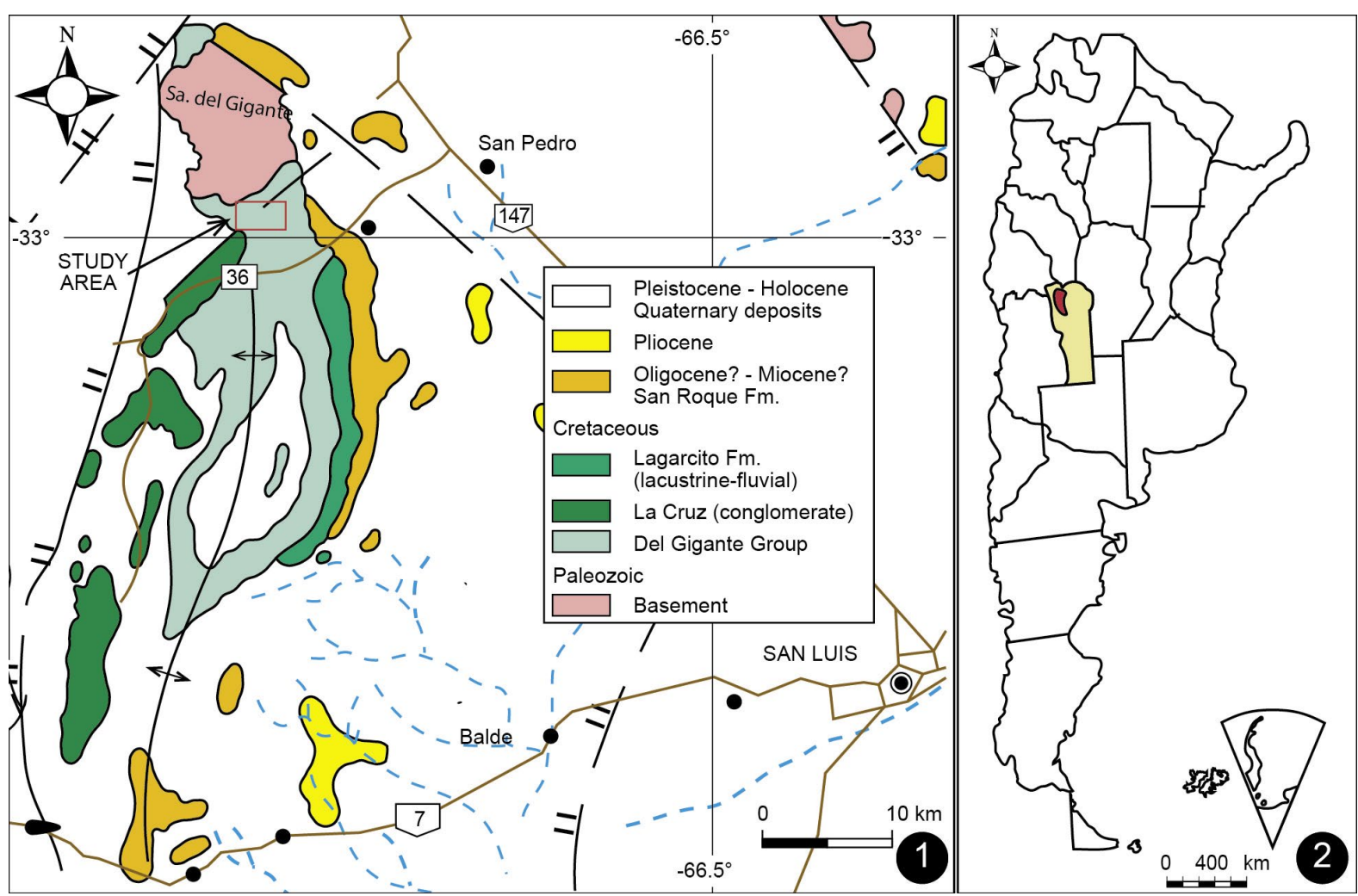

Fig. 1. 1. Geological map showing the La Cantera Formation type locality at Sierra del Gigante (ridge), with exposures of Cretaceous and Cenozoic units in the region (modified from Puebla et al., 2017); 2. Location of San Luis Province, Argentina 


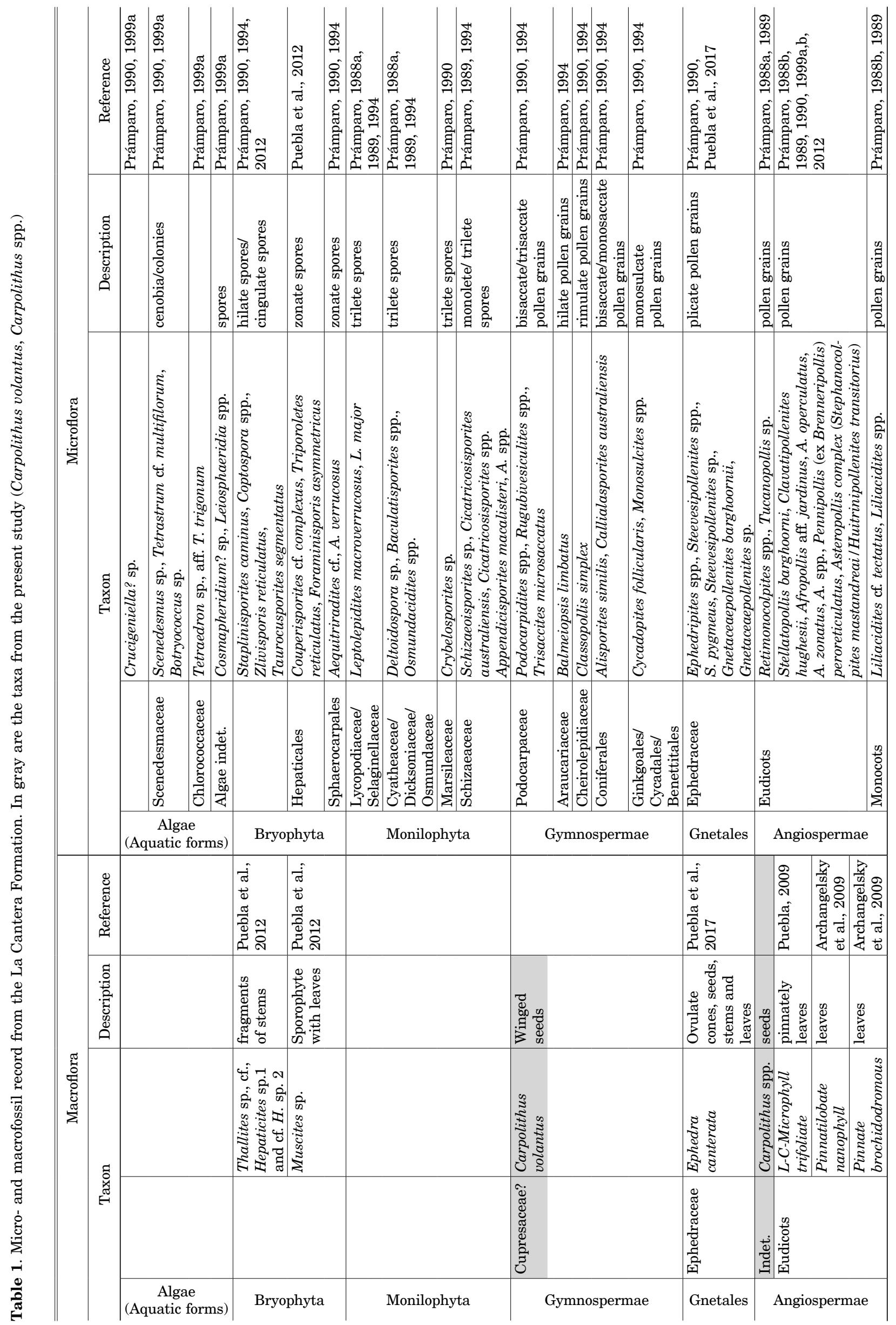


subordinate angiosperms and free-sporing plants (ferns, bryophytes). The gymnosperms are mainly represented by plicate and rimulate grains. Various species of Ephedripites / Steevesipollenites of gnetalean affinity frequently cooccur with monosulcate grains of Cycadopites and Monosulcites. Classopollis (Pinopsida: Cheirolepidiaceae) is also abundant in all the sections. Recently, Puebla et al. (2017) described a new fossil species of Ephedra (E. canterata), based on the presence of ovulate cones associated with vegetative remains and the female reproductive unit (Tab. 1).

\section{SYSTEMATIC PALEONTOLOGY}

Wang (2011) proposed conserving the fossil genus Carpolithus as an informal category used for fossil fruits and seeds that lack sufficient morphological details to make a more accurate generic assignment. In this work we use Carpolithus for relatively simple seeds recovered from the La Cantera Formation. As in previous studies (Puebla et al., 2017), we follow Yang (2011) and call the reproductive units of ovulate cones "female reproductive units".

\section{Subdivision GYMNOSPERMAE Lindley, 1830}

Order GNETALES Blume, 1835

Family EPHEDRACEAE Dumort, 1829

Genus Ephedra L., 1753

Type species: Ephedra distachya Linnaeus, 1753

Ephedra canterata Puebla et al., 2017

Pl. 1

Materials. (Sixteen specimens) MICP-P797, MIC-P798, MIC-P799, MIC-P801, MIC-P802,
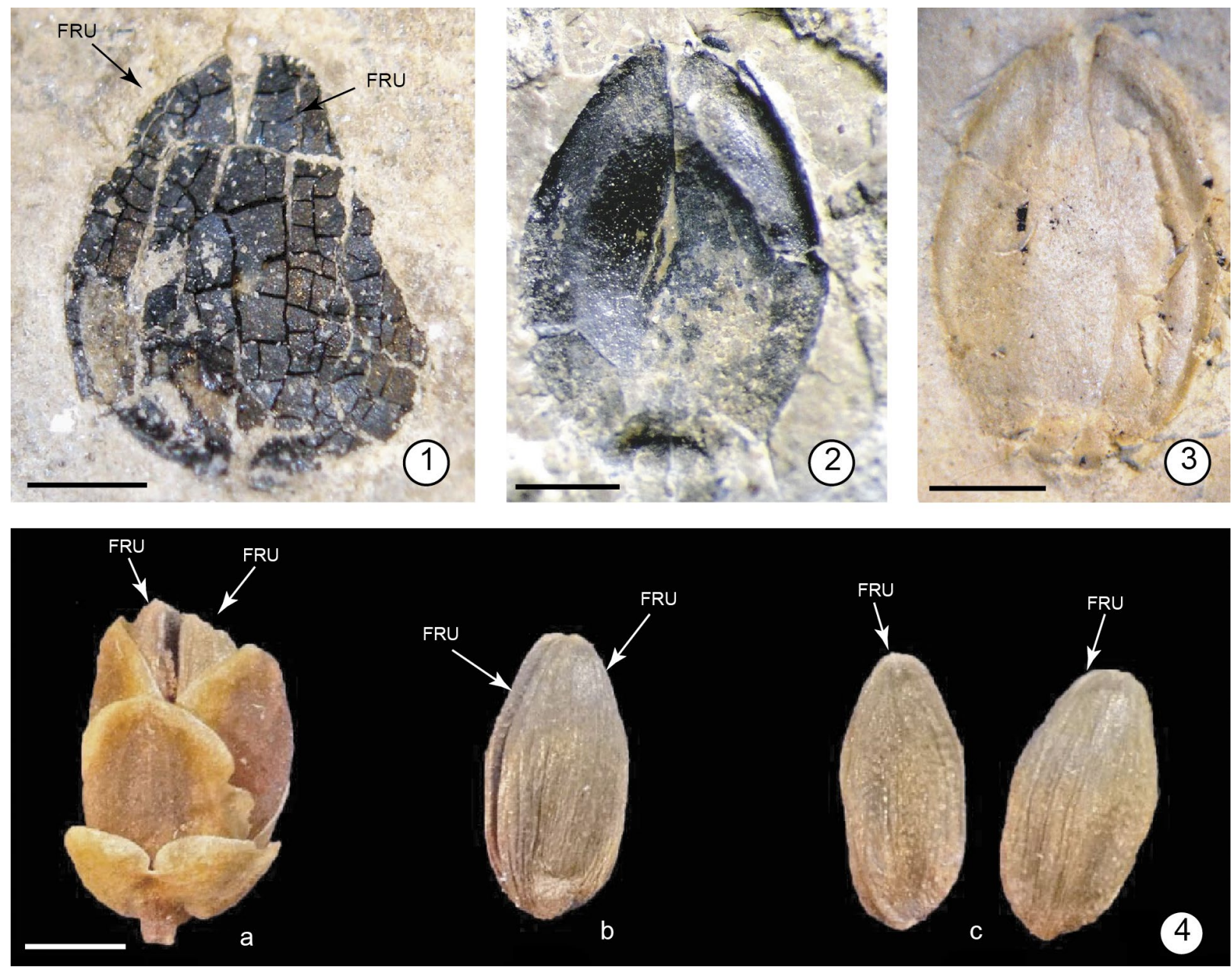

Plate 1. 1-3. Female reproductive units (FRU) of Ephedra canterata. 1. Specimen MIC-P684; 2. Specimen MIC-P852; 3. Specimen MIC-P798; 4. Ephedra chilensis (extant species), a. ovulate cone with bracts, b. FRU (inside cone), c. FRU isolated. Scale bar $=1 \mathrm{~mm}(1,2,3) ; 2 \mathrm{~mm}(4)$ 
MIC-P803, MIC-P804, MIC-P806, MIC-P807, MIC-P811, MIC-P819, MIC-P826, MIC-P830, MIC-P834, MIC-P836, MIC-P852.

Di men si o n s. Width 1.43-3.70, avg. $2.90 \mathrm{~mm}$; length 2.21-4.75, avg. $3.63 \mathrm{~mm}$.

Description. Two female reproductive units joined by flat ventral face; dorsal face convex (Pl. 1, fig. 4a,b). Split of reproductive units (inside cone) evident only at apex (Pl. 1, figs 1-3, 4a,b). Outer epidermis papillate; among these papillae is a central large rounded protuberance interpreted as a trichome base. Whorls of bracts from ovulate cones not preserved.

Remarks. We include these specimens in Ephedra canterata erected by Puebla et al. (2017). The new specimens are consistent with $E$. canterata in size and shape, and they share a papillated outer seed envelope. The original diagnosis includes ovulate cones with fourth whorls of bracts but they are not preserved in the new specimens. The split in the apex probably was due to the arrangement of the ovules in the cone, as occurs in extant species (Pl. 1, figs $1-3,4 a, b)$.

\section{Isolated Female Reproductive Unit}

Pl. 2

Materials. (Fourteen specimens) MIC-P809, MIC-P814, MIC-P827, MIC-P832, MIC-P833, MIC-P838, MIC-P848, MIC-P849, MIC-P850, MIC-P855, MIC-P856, MIC-P858, MIC-P859, MIC-P860.

Dimensions. Width 1-3.42, avg. $2.64 \mathrm{~mm}$; length 2.12-4.92, avg. $3.65 \mathrm{~mm}$.

Description. Seed ovoid-ellipsoid, with acuminate chalaza and rounded apex. These isolated structures are not connected to ovulate cones, and it is not possible to differentiate the three distinctive layers (outer seed envelope, integument and nucellus). Outer epidermis papillated; between the papillae is a large central rounded protuberance, interpreted as a trichome base (Pl. 2, fig. 9).

Remarks. The studied specimens are considered to be isolated seeds because they are not attached to ovulated cones. They have the size, shape and papillae sculpture of the seed envelope, similar to the isolated female reproductive units described by Puebla et al. (2017).
Family Incertae Sedis

Fossil Genus Carpolithus

Linnaeus emend. Seward, 1917

Type species: Carpolithus thalictroides

Brongniart, 1822

Carpolithus volantus sp. nov.

Pl. 3

Holoty pe. MIC-P810 (Pl. 3, fig. 4).

P a r a ty p e. MIC-P808, MIC-P812, MIC-P813, MIC-P815, MIC-P816, MIC-P817, MIC-P818, MIC-P821, MIC-P822, MIC-P823, MIC-P824, MIC-P825, MIC-P829, MIC-P831, MIC-P844, MIC-P846, MIC-P847 (Pl. 3, figs 1-3, 5-9).

Type locality. Type section of the La Cantera Formation $\left(32^{\circ} 59^{\prime} 25^{\prime \prime} \mathrm{S}, 66^{\circ} 52^{\prime} 48^{\prime \prime} \mathrm{W}\right)$, San Luis Province, Argentina.

Derivation nominis. volantus (Latin): the specific epithet refers to dispersal strategy by wind.

Diagno sis. Winged and flattened seeds up to $4 \mathrm{~mm}$ in width or length, with two symmetric wings flanking a narrow elliptic central seed body.

Dimensions. Width of reproductive structure 1.16-3.96, avg. $2.58 \mathrm{~mm}$, length $1.55-$ 3.61, avg. $2.13 \mathrm{~mm}$; width of seed body $0.42-$ 1.23, avg. $0.75 \mathrm{~mm}$, length $1.24-2.79$, avg. $1.92 \mathrm{~mm}$. Width of each wing $0.66-1.70$, avg. $1.04 \mathrm{~mm}$, length $0.75-3.61$, avg. $1.95 \mathrm{~mm}$ (see Fig. 2).

Description. Flattened winged seeds. Central seed body flanked by two membranous wings. Seed body narrow and elliptic, with smooth surface. Acute apex and rounded chalaza. Apex extended into narrow projection probably corresponding to micropylar tube (Pl. 3, figs 4-9). Wings equal in size and shape and wider than body of seed. Some specimens have fine striations at base of wings that extend to more than mid-length. These striations also run along edge of seed body (Pl. 3, figs 1-5). Studied specimens have two wing morphotypes: (a) wings completely surrounding the seed body ( $\mathrm{Pl}$. 3, figs 1-3) and (b) wings reaching around half the length of the seed body (Pl. 3, figs 4-9). 

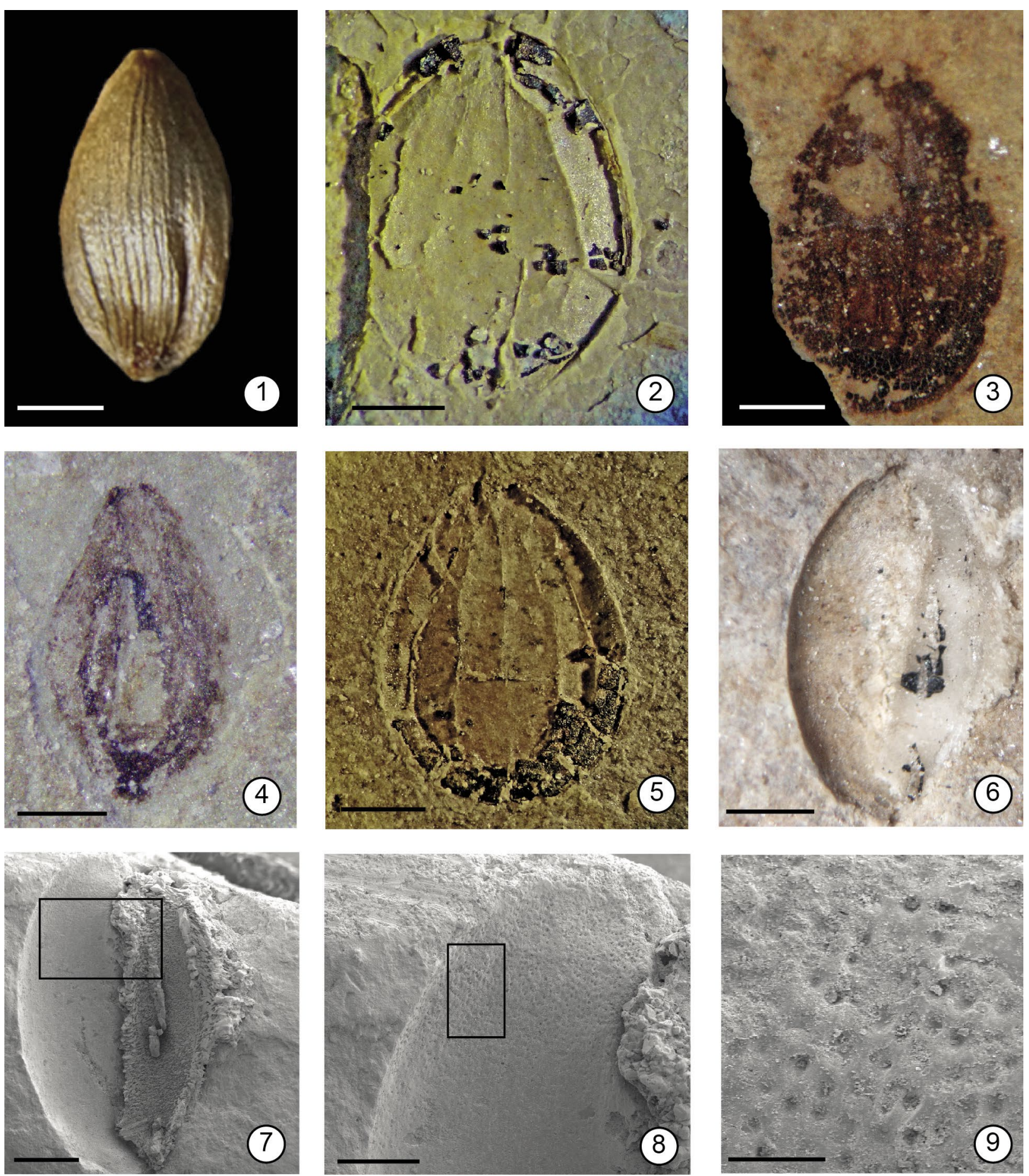

Plate 2. 1. Extant seed of Ephedra chilensis. 2-9. FRU isolated from Ephedra canterata. 2. Specimen MIC-P856; 3. Specimen MIC-P809; 4. Specimen MIC-P849; 6-9. Specimen MIC-P827; 7-9. SEM images showing impression of outer envelope of seed. Scale bar = $0.5 \mathrm{~mm}(4) ; 1 \mathrm{~mm}(3,5,6,7) ; 2 \mathrm{~mm}(1) ; 200 \mu \mathrm{m}(8) ; 100 \mu \mathrm{m}(9)$

Remarks. Carpolithus volantus is the most abundant type of fossil seed recovered from the La Cantera Formation. Unfortunately, all specimens of this species occur isolated, with no organic connection to a reproductive axis.

Botanical affinity and comparisons. Fossil seeds corresponding to Carpolithus volantus have morphological characters similar to gymnosperm seeds of two families: Cupressaceae and Welwitschiaceae. Cupressaceae has an extensive fossil record from the Middle Jurassic (Escapa et al., 2008; Spencer et al., 2015). The Cretaceous was an important time for diversification of this family (Stockey et al., 2005). Extant representatives occur in both hemispheres (Harris, 1979; Rothwell et al., 2011). Seeds from this family are consistent 

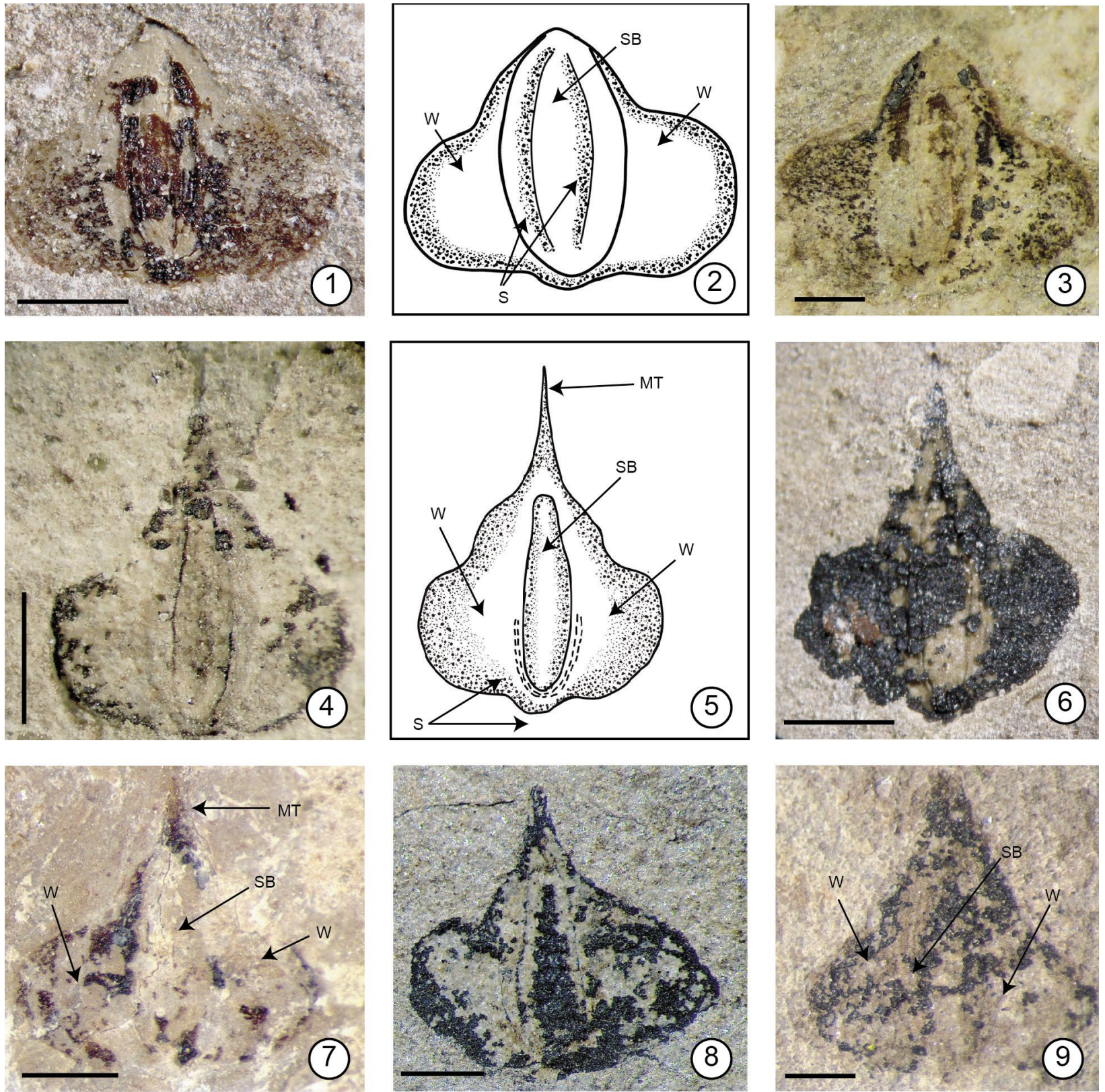

Plate 3. Carpolithus volantus; 1. Specimen MIC-P846; 2. Line drawing of MIC-P822 showing the striations (S) emerging from base of seed; 3. MIC-P822 showing wings (W) covering half of seed body; 4-9. Specimen with wings completely bordering seed body 4. Specimen MIC-P810 showing narrow projection corresponding to micropylar tube (MT) in apex of seed body (SB); $\mathbf{5}$. Line drawing of MIC-P810; 6. Specimen MIC-P821; 7. Specimen MIC-P825; 8. Specimen MIC-P882; 9. Specimen MIC-P817. Scale bar $=0.5 \mathrm{~mm}(3,1) ; 1 \mathrm{~mm}(4,6-9)$

within each natural genus and have diagnostic characters for classification in terms of shape and wing arrangement (Kvaček et al., 2000). Moreover, seeds of most Cupressaceae genera have two equal wings (e.g. Athrotaxis, Chamaecyparis, Cunninghamia, Thuja, Sequoiadendron, Thujopsis, Cupressus, Fitzroya, Tetraclinis, Widdringtonia, Neocallitropsis), like Carpolithus volantus (Pl. 3). However, only a few genera (Athrotaxis, Chamaecyparis, Thuja, Cupressus, Fitzroya) have seeds with dimensions similar to our fossils $(<5 \mathrm{~mm})$. Notably, there are no records of Early Cretaceous seeds of Cupressaceae similar to those from the La Cantera Formation. Gnetophytes had their peak diversity during the Cretaceous, based on palynological data (Krassilov, 1982; Crane and Upchurch, 1987; Rydin et al., 2003; Dilcher et al., 2005; Taylor et al., 2009). Currently, Gnetales is represented by three monogeneric families: Gnetaceae, Ephedraceae and Welwitschiaceae, which all share reproductive characters (Rydin et al., 2006; Kunzman et al., 2011). Welwitschia mirabilis, the single extant species of Welwitschiaceae, is geographically restricted to the arid coastal fringe of Namibia 


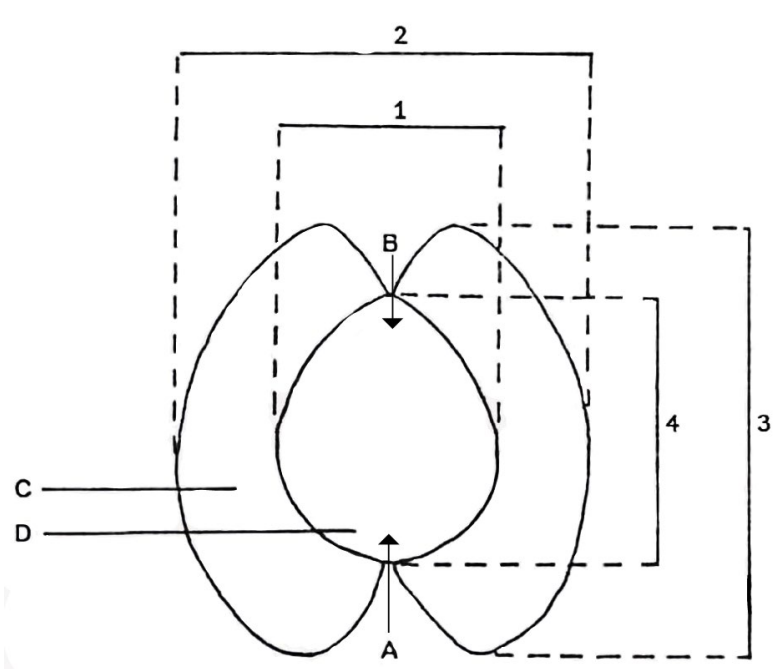

Fig. 2. Line drawing (modified of Lele, 1969) showing the main dimensions considered in descriptions of seed morphology: 1. Width of seed body; 2 . Total width of seed; 3 . Length of wings; 4. Length of seed body. A. Chalaza; B. Apex; C. Wing; D. Seed body

and Angola (Bornman et al., 1972). This species produces enclosed seeds in a membranous winged perianth and generally measures more than $2 \mathrm{~cm}$ long (Hooker, 1863; Kubitzki, 1990). Carpolithus volantus shares some morphological characters with Welwitschia, such as membranous wings with a smooth surface that surround the seed body.

The best-studied fossil records of Welwitschialike seeds correspond to Bicatia from the Early Cretaceous of Portugal and North America (Friis et al., 2014). This fossil taxon has been assigned to Welwitschia-like plants, based on the combination of the external morphology of their seeds and in situ pollen (Friis et al., 2014). Bicatia shares with Carpolithus volantus the flattened winged seed, but it does not exceed $1 \mathrm{~mm}$ width and $1.3 \mathrm{~mm}$ length; Carpolithus volantus is more than $1 \mathrm{~mm}$ wide and $1.5 \mathrm{~mm}$ long (Pl. 3). Additionally, Bicatia has a rough surface that differs from the smooth surface of Carpolithus volantus.

Krassilov and Schrank (2011) described Qataniaria with a probable affinity to Gnetales from the upper Albian of the Hatira Formation, Makhtesh Qatar, northern Negev, Israel. The associated fruiting bodies are enclosed in cataphylls similar to the foliage. The structures are also considered gnetophytic, with lobed wings that probably correspond to persistent bracteoles as in Welwitschia. Qataniaria shares with Carpolithus volantus the presence of wings and similar measurements. However, the fossils from Israel lack a detailed description for further comparisons.

\section{Subdivision ?ANGIOSPERMAE \\ Lindley, 1830}

Family Incertae Sedis

Carpolithus spp.

Pl. 4

Referred materials. (sixteen specimens) MIC-P800, MIC-P820, MIC-P835, MIC-P837, MIC-P839, MIC-840, MIC-P842, MIC-P851, MIC-P853, MIC-P864.

Dimensions. Width $0.68-2$, avg. $0.99 \mathrm{~mm}$, length $0.68-2$, avg. $1.29 \mathrm{~mm}$.

Description. Isolated seeds small $(<2 \mathrm{~mm})$, rounded or narrow and elliptic. Rounded apex and chalaza. Some specimens have smooth surface (Pl. 4, figs 1-6) and others have keel-like structure (Pl. 4, fig.7). Some have micropylelike structure at apex (Pl. 4, figs 1-3, 7-8).

Remarks. The specimens included in Carpolithus spp. are less than $2 \mathrm{~mm}$ in size; they are smaller than the other fossil seeds described from the La Cantera Formation. Although some differences between the specimens included in Carpolithus spp. can be observed, they do not preserve many anatomical characters to assign them a definite botanical affinity.

Botanical affinity and comparisons. The diminutive seeds included in Carpolithus spp. lack any obvious architectural modifications for dispersal (Pl. 4). Angiosperms dominate the macroflora of the La Cantera Formation and are represented by a record including leaves and reproductive structures (Archanglesky et al., 2009; Puebla, 2009, 2010; Tab. 1). These early fossil flowers are very small and presumably produced tiny seeds. Based on their abundance and small size, Carpolithus spp. could be related to angiosperms.

\section{DISCUSSION}

\section{THE EVOLUTION OF SEED SIZE}

Seed size is critical to many aspects of plant ecology and evolution (Harper et al., 1970; Westoby et al., 1996; Leishman et al.; 2000; Moles et al.; 2005a,b; Eriksson, 2008). Several authors have shown a correlation between 

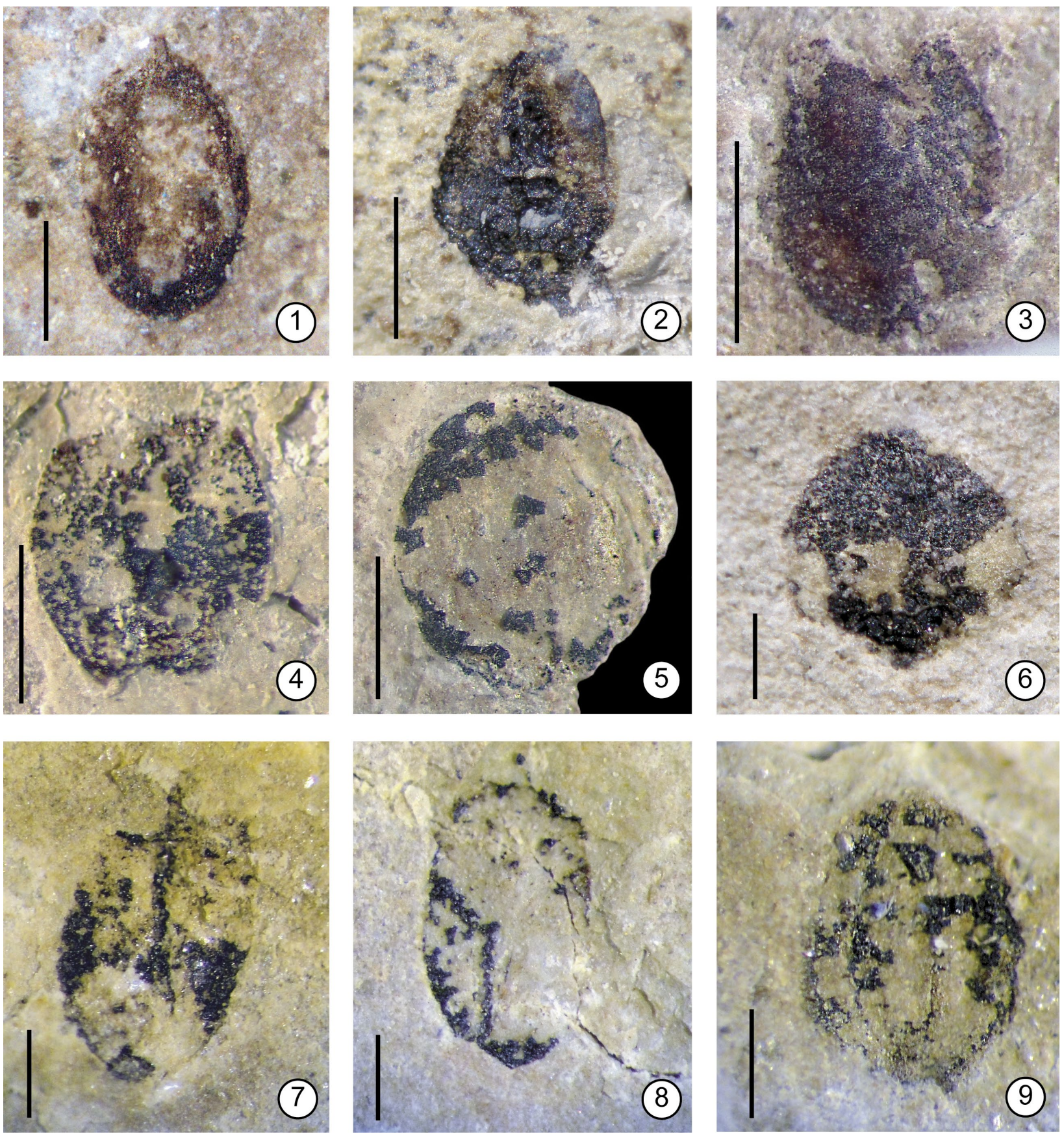

Plate 4. Carpolithus spp. 1. Specimen MIC-P800; 2. Specimen MIC-P820; 3. Specimen MIC-P880; 4. Specimen MIC-P853; 5. Specimen MIC-P881; 6. Specimen MIC-P671; 7. Specimen MIC-P839; 8. Specimen MIC-P835; 9. Specimen MIC-P851. Scale bar $=0.5 \mathrm{~mm}$

habit, habitat, size and seed number. For example, ephemeral plants of open or unstable habitats generally produce many small seeds that can be widely dispersed, often by abiotic mechanisms (Salisbury, 1942; Harper et al., 1970; Silvertown, 1981; Tiffney, 1984; Shipley and Dion, 1992; Eriksson, 2008). Openness of vegetation explains why seeds remained small during the Cretaceous and biotic dispersal was not promoted (Eriksson et al., 2000). A comparative study of angiosperm seed size from the Early Cretaceous to the Neogene suggests that small seeds prevailed until the Late Cretaceous, and seed dispersal was mostly abiotic (Eriksson et al., 2000; Moles et al., 2005b). From the Late Cretaceous to the Paleogene there was a marked increase in the average size of seeds, equivalent to about 2-3 orders of magnitude (Eriksson, 2008). Therefore it is probable that the earliest angiosperms were herbaceous plants (Doyle, 1996; Eriksson, 2008). The angiosperm fossil leaves recovered from the La Cantera are small (0.1$2.7 \mathrm{~cm}$ long, $0.1-1 \mathrm{~cm}$ wide), so it is inferred 
that they were probably herbaceous (Puebla, 2009, 2010), and some of the specimens studied here (Carpolithus spp.) could belong to this group (Pl. 4).

The difference in seed mass between gymnosperms and angiosperms is evident both in the fossil record and in the extant species. In the Cretaceous, the smallest gymnosperm seeds are about two orders of magnitude larger than the smallest angiosperm seeds (Moles et al., 2005b). Small Cretaceous seeds probably belonged to angiosperms that were shrubs, small trees or even herbs (Wing and Tiffney, 1987; Wing and Boucher, 1998; Eriksson, 2008). The European and North American fossil angiosperms from Cretaceous strata all have small reproductive organs, with the dimensions of seeds, fruits and flowers varying between 0.5 and $3 \mathrm{~mm}$ (Frumin and Friis, 1999; Rydin et al., 2006).

\section{ANALYSIS OF DISPERSAL STRATEGIES IN SPORES, POLLEN GRAINS AND SEEDS}

We analyzed the dispersal strategies of plants from the La Cantera Formation, based on micro- and macrofossils (Tab. 1).

\section{Bryophyta}

The bryophytes sensu lato were important components of early terrestrial floras (Bateman et al., 1998; Renzaglia et al., 2007), with a wide range of habitats (Mishler, 2001). The Cretaceous saw an evolutionary radiation and dispersion of bryophytes. Fossil remains found from this period are easily assigned to extant genera because their morphology is conservative (Frahm, 1994; Taylor et al., 2009). In the La Cantera Formation, spores together with diverse macrofossils belonging to Bryophyta were recovered from the same fossiliferous strata. Puebla et al. (2012) found predominance of spores and thalli with hepatic affinities within the assemblage. The record of trilete spores of Bryophytes is sparse, represented by the hilates such as Couperisporites sp. cf. C. complexus, Aequitriradites sp. cf. A. verrucosus, Foraminisporis symetricus, Zlivisporis reticulatus and Coptospora spp. (Puebla et al., 2012) (Tab. 1).

Bryophytes are ecologically sensitive, small (a few millimeters to decimeters), niche-specific, and intolerant to seawater. Generally they need a humid environment for their development (Bates et al., 2009). The La Cantera Formation represents ephemeral lake deposits of a fluvial floodplain setting (Flores and Criado Roque, 1972), which allowed preservation of delicate structures such as bryophyte thalli.

Sexual reproduction of these plants is strongly related to the availability of water because male gametes move only short distances (Longton and Schuster, 1983; Hedderson and Longton, 1995; Bell and Hemsley, 2000; During, 2007; Frahm, 2007; Vanderpoorten and Goffinet, 2009; Devos et al., 2011). In asexual reproduction, spores disperse mainly by wind (anemochory) (Zander, 1979).

\section{Monilophyta}

During the Early Cretaceous, ferns grew and accumulated under warm conditions in moist environments including wetlands, mires, riverbanks and the understory of forests (Collinson, 2002; Van Konijnenburgvan Cittert, 2002). Two families were particularly important during the Early Cretaceous: Osmundaceae and Schizaeaceae. Modern Schizaeaceae are distributed in warm and humid environments (Skog, 2001). Their spores are dispersed mainly by wind and water (Traverse, 1988). Most ferns are homosporous. These ferns have free-living bisexual gametophytes, so they can establish new populations in distant places by scattering individual spores. For these reasons, ferns can respond more readily to environmental changes than flowering plants can (Kato, 1993). Monilophyta are represented in the La Cantera paleoflora by diverse but not abundant spores (Prámparo, 1989). Spores belonging to the homosporic ferns Lycopodiaceae, Cyatheaceae, Dicksoniaceae and Schizaeaceae, and the heterosporous ferns Marsileaceae and Selaginellaceae, occur in the palynoflora (Prámparo, 1989, 1990, 1994) (Tab. 1). So far, ferns have not been recorded in the macroflora.

\section{Gymnospermae}

During the Mesozoic, gymnosperms including cycads, conifers and ginkgos reached their peak in species richness and ecological importance (Harris, 1979; Thomas and Spicer, 1986; Henry, 2005). The Mesozoic is considered the golden age of conifers, given their expansive 
radiation and floristic dominance (Harper et al., 1970).

Gnetales are a group of interest to botanists because their relationships with other seed plants are still unknown (Crane et al., 2004; Ickert-Bond and Renner, 2016). Recently the new species Ephedra canterata was described from the La Cantera Formation, based on vegetative and reproductive remains (Puebla et al., 2017). Plicate pollen grains are also very abundant and diverse in the palynoflora (Tab. 1). The Ephedripites complex (= pollen grains of gnetalean affinity) includes Ephedripites spp. Gnetaceapollenites spp., Steevesipollenites spp. and Jugella spp. (Prámparo, 1990; Prámparo et al., 2018; Puebla et al., 2017). The abundant plicate pollen grains associated with the macrofossils confirm the strong representation of this group in the basin (Puebla et al., 2017).

The modern representatives of Ephedra grow in dry environments; their abundance during the Cretaceous could be related to the warmer and drier environments that developed in tropical and subtropical regions during this period (Scotese et al., 1999; Wang and Zheng, 2010). The cones of Ephedra canterata have dry membranous bracts and small seeds, so anemochory is inferred as the mechanism of dispersal of these seeds (Puebla et al., 2017). This morphology is evident in seeds of some extant species of Ephedra (Section Alatae), which are wind-dispersed (Hollander and Wall, 2009; Hollander et al., 2010). The abundant record of Ephedra in the La Cantera Formation (indicative of dry, even arid conditions) suggests a marked arid season in the basin during the late Aptian (Puebla et al., 2017; Prámparo et al., 2018).

Cheirolepidiaceae is an extinct conifer group dating to the Late Triassic (Axsmith and Jacobs, 2005); it disappeared around the Cretaceous/Paleogene boundary in most areas, except in southern Argentina, where it has also been recorded from the Early Paleogene (Barreda et al., 2012). This family was a characteristic and abundant element of lowlatitude Cretaceous floras, mainly represented by Classopollis pollen (Alvin, 1982). It is also a frequent and abundant component of Early Cretaceous palynofloras of Argentina (Quattrocchio et al., 2011; Villar de Seoane and Archangelsky, 2014; Prámparo et al., 2018) and other high-latitude parts of Gondwana (Tosolini et al., 2015). Classopollis, together with pollen grains of Gnetales (mainly those with Ephedra and Welwitschia affinity), have been used as indicators of aridity in paleoclimatic reconstructions, mainly in low to middle latitudes (Herngreen, 1996; Mejia-Velasquez et al., 2012; Prámparo et al., 2018).

The La Cantera Formation yielded abundant pollen grains of Classopollis at some levels (Prámparo, 1989, 1990, 1994). The abundance of these pollen grains, together with Gnetalean pollen, both inferred to be droughtresistant, indicate an expanding hot arid climate during the Aptian-Albian in the middle and low latitudes of Argentina (Prámparo et al., 2018). However, there are no records of conifer macrofossils in the basin. The La Cantera Formation palynoflora contains monosulcate grains of the fossil genera Cycadopites and Monosulcites (Prámparo, 1989, 2012) (Tab. 1). Most of the Cycadopites/Monosulcites pollen grains from the Late Jurassic to Early Cretaceous originated from Ginkgoales, Cycadales and Bennettitales that grew in lowland vegetation (Vakhrameev, 1991; Abbink et al., 2004). In addition, pollen grains related to Podocarpaceae (Podosporites sp. 1, Rugubivesiculites spp. 1-2 and Trisaccites microsaccatus), Araucariaceae (Balmeiopsis limbatus) and other Coniferales (Alisporites similis, Callialasporites australiensis) have been found in La Cantera (Prámparo, 1990, 1994) (Tab. 1). However, there are no records of these taxonomic groups in the macroflora so far.

Most gymnosperms are wind-pollinated, but beyond this, two main dispersal syndromes are known for the group. One of the dispersal syndromes consists of woody or coriaceous cones that generally contain winged seeds that are dispersed by wind (anemochory) or by gravity (barochory). The other consists of fleshy "fruits"/arils that surround wingless seeds that are dispersed by animals (zoochory) (Giddy, 1974; Givnish, 1980; McLoughlin and Pott, 2019).

The seeds included in Carpolithus volantus of the La Cantera Formation are doublewinged (Pl. 3). The presence of such appendages indicates that anemochory was an important dispersal strategy (McLoughlin and Pott, 2019). Seed wings, especially double wings, provide improved aerodynamic properties, reducing the rates of descent and optimizing seed dispersal (Souza and Iannuzzi, 2012; Stevenson et al., 2015). The presence of this 
morphological feature in Carpolithus volantus emphasizes anemochory as the main dispersal strategy for these seeds.

\section{Angiospermae}

The Cretaceous is crucial for understanding the evolution and radiation of angiosperms, one of the most important events in the history of the Earth's biota (Taylor and Hickey, 1990; Sun and Dilcher, 2002; Friis et al., 2006). The oldest unequivocal angiosperm remains come from Cretaceous strata and are represented by remains of leaves (Hickey and Doyle, 1977), flowers and floral organs (Friis et al. 2011).

Mesofossil assemblages from Cretaceous (Barremian-Aptian) strata contain an enormous diversity of isolated fruits and seeds (Friis et al., 1999, 2009, 2011). The study of these fossils has great potential for elucidating early angiosperm evolution (Friis et al., 2011). During most of the Cretaceous, angiosperm seeds were small and unspecialized (Tiffney, 1984; Friis and Crepet, 1987; Friis et al., 1995, 1997; Erikson et al., 2000), so their dispersal was probably abiotic (hydrochory or anemochory) (Tiffney, 1984; Eriksson et al., 2000; Eriksson and Kainulainen, 2011; McLoughlin and Pott, 2019). In the La Cantera Formation palynoflora, angiosperms are represented by Afropollis (A. operculatus, A. zonatus, A. aff. jardinus), Retimonocolpites sp., Stellatopollis sp., Clavatipollenites sp., Tucanopollis, Pennipollis (ex Brenneripollis) reticulatus and the Asteropollis complex (Stephanocolpites mastandreai/Huitrinipollenites transitorius (Prámparo, 1999b; Prámparo et al., 2007). In addition, early angiosperm remains have been found as leaves, some of which are assigned to the eudicots (LC-Microphyll trifoliate) (Archangelsky et al., 2009; Puebla, 2009), and small flowers (Puebla, 2010) (Tab. 1). These remains are all small (0.1-2.7 cm; Puebla, 2009, 2010).

The seeds included in Carpolithus spp. from the La Cantera Formation are very small $(<2 \mathrm{~mm})$ and unspecialized morphologically (Pl. 4). Seeds of Archaefructus liaoningensis Sun et al. 1998 and Sinocarpus decussatus Leng et Friis 2003 also have no distinctive characters and are generally smooth, ellipsoidal and 1-2 mm long (McLoughlin and Pott, 2019). Therefore, based on the characters of Carpolithus spp., it is inferred that this type of seed could have been produced by small angiosperms and may be related to the small fossil flowers recovered from the basin. Owing to its proximity to a lacustrine environment, Carpolithus spp. $(<2 \mathrm{~mm})$ could have been dispersed by wind or water.

\section{CONCLUSIONS}

Fossil seeds from the late Aptian of the La Cantera Formation, San Luis Basin, central western Argentina, are described and illustrated here for the first time. We described a new species of Carpolithus, plus additional specimens attributed to Carpolithus and $E$. canterata. These new fossils expand the floristic diversity of the San Luis Basin during the Early Cretaceous.

We discussed the botanical affinity of winged seeds assigned to Carpolithus volantus in the context of the entire plant association recovered from the formation. Thus, two alternative affinities are possible for the winged seed types: Cupressaceae or Welwitschiaceae. Their preservation as impressions or thin compressions precludes a detailed anatomical comparison (Pl. 3). Nevertheless, it is noteworthy that there is currently no evidence (within the macro- or microflora) of the presence of Cupressaceae in the La Cantera Formation. On the other hand, the discovery of E. canterata and abundant and diverse polyplicate pollen grains confirms the strong representation of Gnetales in the San Luis Basin (Tab. 1). Furthermore, among polyplicate grains, those that have a longitudinal aperture and probable affinity to Welwitschia were recognized in the microflora (Puebla et al., 2017). Thus, we deduced a more probable relationship of Carpolithus volantus to Gnetales.

Angiosperms are the dominant group in the macroflora of the La Cantera Formation (Puebla, 2010), being represented by small leaves (0.1-2.7 cm long, $0.1-1 \mathrm{~cm}$ wide) and flowers $(<6 \mathrm{~mm})$ (Puebla, 2009, 2010), so it is inferred that they were herbaceous plants. We suggest that some of the seeds studied here (Carpolithus spp.) could belong to this group.

Our analysis of the total floristic association (micro- and macroflora) of the La Cantera Formation and their morphological adaptations indicates that their dispersal strategy was mainly anemochory. However, we cannot exclude hydrochory as a dispersal strategy for small seeds. 


\section{ACKNOWLEDGEMENTS}

We thank E. Crespo for obtaining images from the LABMEM microscopy service of San Luis University (UNSL), the curators and technicians of the Museo Argentino de Cs. Naturales for granting access to collections, Barbara Vento for valuable comments on the text, F. Gianechini and G. Castillo-Elías for help with figures, and the reviewers for their constructive remarks on the manuscript. Financial support for this work was provided by Consejo Nacional de Investigaciones Científicas y Técnicas (PIP 2014-2016 PIP CONICET 11220130100444 CO), the National University of San Luis (PROICO 02-0618) and Agencia Nacional de Promoción Científica y Tecnológica (Proyectos de Investigación Científica y Tecnológica 2017-0809).

\section{REFERENCES}

Abbink, O.A., Van Konijnenburg-Van Cittert, J.H.A., Visscher, H., 2004. A sporomorph ecogroup model for the Northwest European Jurassic-Lower Cretaceousi: concepts and framework. Netherlands Journal of Geosciences 83(1), 17-31.

Alvin, K.L., 1982. Cheirolepidiaceae: biology, structure and paleoecology. Review of Palaeobotany and Palynology 37(1-2), 71-98.

Archangelsky, A., 2000. Estudio sobre semillas neopaleozoicas de Argentina. Boletín de la Academia Nacional de Ciencias, 64: 79-115.

Archangelsky, S., Barreda, V., Passalia, M.G., Gandolfo, M., Prámparo, M., Romero, E., Cúneo, R., Zamuner, A., Iglesias, A., Llorens, M., Puebla, G., Quattrocchio, M., Wolfgang, V., 2009. Early angiosperm diversification: evidence from southern South America. Cretaceous Research 30(5), 1073-1082.

Arcucci, A.B., Prámparo, M.B., Codorniú, L., Giordano, G., Castillo Elías, G., Puebla, G., Mego, N., Gómez, M., Bustos Escalona, E., 2015. Biotic assemblages from lower Cretaceous lacustrine systems, San Luis Basin, central-western Argentina. Boletín Geológico y Minero 126, 109-128.

Austen, P.A., Batten, D.J., 2018. English Wealden fossils: an update. Proceedings of the Geologists' Association 129(2), 171-201.

Axsmith, B.J., Jacobs, B.F., 2005. The conifer Frenelopsis ramosissima (Cheirolepidiaceae) in the Lower Cretaceous of Texas: systematic, biogeographical, and paleoecological implications. International Journal of Plant Sciences 166(2), 327-337.

Ballent, S., Carignano, A.P., Iglesias, A., Poiré, D.G., 2011. Microfósiles Calcáreos no Marinos y semillas de la Formación Piedra Clavada (Albiano) en su área Tipo, Provincia de Santa Cruz, Argentina. Ameghiniana 48(4), 541-555.

Barreda, V.D., Cúneo, N.R., Wilf, P., Currano, E.D., Scasso, R.A., Brinkhuis, H., 2012. Cretaceous/Paleogene floral turnover in Patagonia: drop in diversity, low extinction, and a Classopollis spike. PLoS One 7(12), e52455.
Bateman, R.M., Crane, P.R., DiMichele, W.A., Kenrick, P.R., Rowe, N.P., Speck T., Stein, W.E., 1998. Early evolution of land plants: phylogeny, physiology, and ecology of the primary terrestrial radiation. Annual Review of Ecology and Systematics 29(1), 263-292.

Bates, J.W., Wibbelmann, M.H., Proctor, M.C., 2009. Salinity responses of halophytic and non-halophytic bryophytes determined by chlorophyll fluorometry. Journal of Bryology 31(1), 1119.

Batten, D.J., Zavattieri, A.M., 1995. Occurrence of dispersed seed cuticles and similar microfossils in mainly Cretaceous successions in the Northern Hemisphere. Cretaceous Research 16, 73-94.

Batten, D.J., Zavattieri, A.M., 1996. Re-examination of seed cuticles from Cretaceous deposits in West Greenland. Cretaceous Research 17(6), 691-713.

Bell, P.R., Hemsley, A.R., 2000. Green plants: their origin and diversity. Cambridge, UK: Cambridge University Press.

Benedict, J.C., Smith, S.Y., Collinson, M.E., LeongŠkorničková, J., Specht, C.D., Fife, J.L., Marone, F., Xiao, X., Parkinson, D.Y., 2015. Evolutionary significance of seed structure in Alpinioideae (Zingiberaceae). Botanical Journal of the Linnean Society 178(3), 441-466.

Benedict, J.C., Smith, S.Y., Collinson, M.E., LeongŠkorničková, J., Specht, C.D., Marone, F., Xia, X., Parkinson, D.Y., 2016. Seed morphology and anatomy and its utility in recognizing subfamilies and tribes of Zingiberaceae. American Journal of Botany 102(11), 1814-1841.

Blume, K.L., 1835. Order D. Gnetales. C.F.P. von Martius, Consp. Regn. Veg.

Bornman, C.H., Elsworthy, J.A., Butler, V., Botha, C. E.J. 1972. Welwitschia mirabilis: observations on general habit, seed, seedling and leaf characteristics. Madoqua (II) 1: 53-66.

Brongniart, A., 1822. Carpolithus. Mémoires Du Muséum National D’histoire Naturelle 8, 319.

Castillo-Elías, G., Prámparo, M.B., Sánchez, M.L., 2016. El importante rol de las estructuras tipo MISS en la preservación fosilífera en un ambiente continental: Formación La Cantera (Aptiano tardío), Cuenca de San Luis. $11^{\circ}$ Congreso de la Asociación Paleontológica Argentina 1, 158-159 (Rio Negro, Argentina).

Chang, M.M., Chen, P.J., Wang, Y.Q., Wang, Y., 2003. The Jehol Biota: The Emergence of Feathered Dinosaurs, Beaked Birds and Flowering Plants. Shanghai Scientific and Technological Publishers, Shanghai.

Collinson, M.E., 2002. The ecology of Cainozoic ferns. Review of Palaeobotany and Palynology 119(1-2), 51-68.

Crane, P.R., Upchurch, Jr G.R., 1987. Drewria potomacensis gen. et sp. nov., an Early Cretaceous member of Gnetales from the Potomac Group of Virginia. American Journal of Botany 74(11), 1722-1736.

Crane, P.R., Pedersen, K.R., Friis, E.M., Drinnan, A.N., 1993. Early Cretaceous (Early to Middle Albian) 
platanoid inflorescences associated with Sapindopsis leaves from the Potomac Group of Eastern North America. Systematic Botany 18, 328-344.

Crane, P.R, Herendeen, P., Friis, E.M., 2004. Fossils and plant phylogeny. American Journal of Botany 91, 1683-1699.

Criado Roque, P., Mombru, C.A., Moreno, J., 1981. Sedimentitas mesozoicas. In: Geología y Recursos Naturales de la Provincia de San Luis. Relatorio del VII Congreso Geológico Argentino, 79-96.

Devos, N., Renner, M.A.M., Gradstein, R., Shaw, A.J., Laenen, B., Vanderpoorten, A., 2011. Evolution of sexual systems, dispersal strategies and habitat selection in the liverwort genus Radula. New Phytologist 192, 225-236.

Dilcher, D.L., Bernardes-De-Oliveira, M.E., Pons, D.Y., Lott, T.A., 2005. Welwitschiaceae from the Lower Cretaceous of northeastern Brazil. American Journal of Botany 92(8), 1294-1310.

Doyle, J.A., 1996. Seed plant phylogeny and the relationships of Gnetales. International Journal of Plant Sciences, 3-39.

Drinnan, A.N., Chambers, T.C., 1986. Flora of the Lower Cretaceous Koonwarra Fossil Beds (Korumburra Group), South Gippsland, Victoria. Association of Australasian Palaeontologists Memoir 3, 1-77.

Dumortier, B.C.J., 1829. Familia 6 Ephedraceae. Analyse des Familles des Plantes, 11.

During, H.J., 2007. Relations between clonal growth, reproduction and breeding system in the bryophytes of Belgium and The Netherlands. Nova Hedwigia, Beiheft 131, 133-145.

Eriksson, O., 2008. Evolution of seed size and biotic seed dispersal in angiosperms: paleoecological and neoecological evidence. International Journal of Plant Sciences 169(7), 863-870.

Eriksson, O., Kainulainen, K., 2011. The evolutionary ecology of dust seeds. Perspectives in Plant Ecology, Evolution and Systematics 13(2), 73-87.

Eriksson, O., Friis, E.M., Löfgren, P., 2000. Seed size, fruit size, and dispersal systems in angiosperms from the Early Cretaceous to the Late Tertiary. The American Naturalist 156(1), 47-58.

Escapa, I., Cúneo, R., Axsmith, B., 2008. A new genus of the Cupressaceae (sensu lato) from the Jurassic of Patagonia: implications for conifer megasporangiate cone homologies. Review of Palaeobotany and Palynology 151(3-4), 110-122.

Flores, M., 1969. El Bolsón de Las Salinas en la Provincia de San Luis. Actas de las Cuartas Jornadas Geológicas Argentinas, I, 311-327 (Mendoza, Argentina).

Flores, M., Criado Roque, P., 1972. Cuenca de San Luis. $1^{\circ}$ Simposio de Geología Regional Argentina. Academia Nacional de Ciencias Córdoba, 567-580 (Córdoba, Argentina).

Frahm, J.P., 1994. Moose-lebende Fossilien. Biologie in unserer Zeit 24(3), 120-124.
Frahm, J.P., 2007. Diversity, dispersal and biogeography of bryophytes (mosses). In Protist diversity and geographical distribution, 43-50 (Springer, Dordrecht).

Frenguelli, J., 1953. (unpubl). La flora fósil de la región del Alto Río Chalía en Santa Cruz (Patagonia). PhD thesis, Universidad Nacional Eva Perón, Facultad de Ciencias Naturales, Buenos Aires.

Friis, E.M., Crepet, W.L., 1987. Time of appearance of floral features. In: Friis, E.M., Chaloner, W.G., Crane, P.R. (eds), The Origins of Angiosperms and their Biological Consequences. Cambridge University Press, pp. 145-179.

Friis, E.M., Pedersen, K.R., Crane, P.R., 1995. Appomattoxia ancistrophora gen. et sp. nov., a new Early Cretaceous plant with similarities to Circaeaster and extant Magnoliidae. American Journal of Botany 82(7), 933-943.

Friis, E.M., Crane, P.R, Pedersen, K.R., 1997. Anacostia, a new basal angiosperm from the Early Cretaceous of North America and Portugal with trichotomocolpate / monocolpate pollen. Grana 36, 225-244.

Friis, E.M., Pedersen, K.R., Crane, P.R., 1999. Early angiosperm diversification: the diversity of pollen associated with angiosperm reproductive structures in Early Cretaceous floras from Portugal. Annals of the Missouri Botanical Garden 86, 259-296.

Friis, E.M., Pedersen, K.R., Crane, P.R., 2006. Cretaceous angiosperm flowers: Innovation and evolution in plant reproduction. Palaeogeography, Palaeoclimatology, Palaeoecology 232, 251-293.

Friis, E.M., Pedersen, K.R., Crane, P.R., 2009. Early Cretaceous mesofossils from Portugal and eastern North America related to the Bennettitales Erdtmanithecales-Gnetales group. American Journal of Botany 96(1), 252-283.

Friis, E.M., Crane, P.R., Pedersen, K.R., 2011. Early flowers and angiosperm evolution. Cambridge University Press.

Friis, E.M., Pedersen, K.R., Crane, P.R., 2014. Welwitschioid diversity in the Early Cretaceous: Evidence from fossil seeds with pollen from Portugal and eastern North America. Grana 53(3), 175-196.

Frumin, S., Friis, E.M., 1999. Magnoliid reproductive organs from the Cenomanian-Turonian of northwestern Kazakhstan: Magnoliaceae and Illiciaceae. Plant Systematics and Evolution 216(3-4), 265-288.

Gandolfo, M.A., Cúneo, R., 2005. Fossil Nelumbonaceae from the La Colonia Formation (Campanian-Maastrichtian, Upper Cretaceous), Chubut, Patagonia, Argentina. Review of Palaeobotany and Palynology 133, 169-178.

Giddy, C., 1974. Cycads of South Africa: With Pencil Drawings and Diagrams by Barbara Jeppe. Purnell.

Giordano, P.G., 2017. Diversity of Cretaceous continental actinopterygians from Argentina, South America. Research and Knowledge 3(2), 1-8.

Givnish, T.J., 1980. Ecological constraints on the evolution of breeding systems in seed plants: dioecy 
and dispersal in gymnosperms. Evolution 34(5), 959-972.

Haig, D., Westoby, M., 1989. Selective forces in the emergence of the seed habit. Biological Journal of the Linnean Society 38(3), 215-238.

Harper, J.L., Lovell, P.H., Moore, K.G., 1970. The shapes and sizes of seeds. Annual Review of Ecology and Systematics 1(1), 327-356.

Harris, T.M., 1979. The Yorkshire Jurassic flora. V. Coniferales. British Museum of Natural History (London).

Hedderson, T.A., Longton, R.E., 1995. Patterns of life history variation in the Funariales, Polytrichales and Pottiales. Journal of Bryology 18(4), 639-675.

Henry, R.J., 2005. Plant diversity and evolution: genotypic and phenotypic variation in higher plants. Cabi Publishing.

Herngreen, G.F.W., 1996. Cretaceous palynofloral provinces: a review. Palynology: principles and applications. American Association of Stratigraphic Palynologists Foundation 3, 1157-1188.

Hickey, L.J., Doyle, J.A., 1977. Early Cretaceous fossil evidence for angiosperm evolution. The Botanical Review 43(1), 3-104.

Hollander, J.L., Vander Wall, S.B., 2009. Dispersal syndromes in North American Ephedra. International Journal of Plant Sciences 170(3), 323-330.

Hollander, J.L., Vander Wall, S.B., Baguley, J.G., 2010. Evolution of seed dispersal in North American Ephedra. Evolutionary Ecology 24(2), 333-345.

Hooker, J.J.D., 1863. On Welwitschia, a new Genus of Gnetaceae. Transactions of the Linnean Society of London 24(1), 1-48.

Ickert-Bond, S.M., Renner, S.S., 2016. The Gnetales: recent insights on their morphology, reproductive biology, chromosome numbers, biogeography, and divergence times. Journal of Systematics and Evolution 54(1), 1-16.

Kato, M., 1993. Biogeography of ferns: dispersal and vicariance. Journal of biogeography, 265-274.

Krassilov, V.A., 1982. Early Cretaceous flora of Mongolia. Palaeontographica Abt. B, 1-43.

Krassilov, V., Schrank, E., 2011. New Albian macroand palynoflora from the Negev (Israel) with description of a new gymnosperm morphotaxon. Cretaceous Research 32(1), 13-29.

Kubitzki, K., 1990. Welwitschiaceae. In: Kramer, K.U., Green, P.S. (eds), Pteridophytes and Gymnosperms. The Families and Genera of Vascular Plants, vol 1. Springer, Berlin, Heidelberg, pp. 387-391.

Kunzmann, L., Mohr, B.A.R., Wilde, V., BernardesDe-Oliveira, M.E.C., 2011. A putative gnetalean gymnosperm Cariria orbiculiconiformis gen. nov. et spec. nov. from the Early Cretaceous of northern Gondwana. Review of Palaeobotany and Palynology, 165: 75-95.

Kvaček, Z., Manchester, S.R., Schorn, H.E., 2000. Cones, seeds, and foliage of Tetraclinis salicornioides
(Cupressaceae) from the Oligocene and Miocene of western North America: a geographic extension of the European Tertiary species. International Journal of Plant Sciences 161(2), 331-344.

Leishman, M.R., Wright, I.J., Moles, A.T., Westoby, M., 2000. The evolutionary ecology of seed size. In: Fenner, M. (ed.), Seeds: The Ecology of Regeneration in Plant Communities, 2nd edn. CABI Publishing, Oxford.

Leng, Q., Friis, E.M., 2003. Sinocarpus decussatus gen. et sp. nov., a new angiosperm with basally syncarpous fruits from the Yixian Formation of Northeast China. Plant Systematics and Evolution 241(1-2), 77-88.

Lindley, J., 1830. An Introduction to the Natural System of Botany. Longman and London.

Linnaeus, C.V., 1753. Species Plantarum, Tomus 1. Stockholm.

Longton, R.E., Schuster, R.M., 1983. New manual of bryology. Reproductive biology, 386-462.

McLoughlin, S., Pott, C., 2019. Plant mobility in the Mesozoic: Disseminule dispersal strategies of Chinese and Australian Middle Jurassic to Early Cretaceous plants. Palaeogeography, palaeoclimatology, palaeoecology 515, 47-69.

Mejía-Velásquez, P.J., Dilcher, D.L., Jaramillo, C., Fortini, L.B., Manchester, S.R., 2012. Palynological composition of a Lower Cretaceous South American Tropical sequence: Climatic implications and diversity comparisons with other latitudes. American Journal of Botany 99, 1819-1827.

Mishler, B.D., 2001. The biology of bryophytes: bryophytes aren't just small tracheophytes. American Journal of Botany 88(11), 2128-2131.

Moles, A.T., Ackerly, D.D., Webb, C.O., Tweddle, J.C., Dickie, J.B., Westoby, M., 2005a. A brief history of seed size. Science 307(5709), 576-580.

Moles, A.T., Ackerly, D.D., Webb ,C.O., Tweddle, J.C., Dickie, J.B., Pitman, A.J., Westoby, M., 2005b. Factors that shape seed mass evolution. Proceedings of the National Academy of Sciences of the United States of America 102(30), 10540-10544.

Musacchio, E.A., Vallati, P., 2007. Late Cretaceous non-marine microfossils of Plottier Formation (Cretaceous) at Zampal, Argentina. Instituto Geológico y Minero de España, Madrid. Cuaderno Geominero 8, 273-278.

Papú, O.H., 2002. Nueva microflora de edad maastrichtiana en la localidad de Calmu-Co, sur de Mendoza, Argentina. Ameghiniana 39(4), 415-426.

Passalia, M.G., Prámparo, M.B., Calvo, J., Heredia, S., 2008. Primer registro de hojas de angiospermas en el Grupo Neuquén (Turoniano tardío Coniaciano temprano), Lago Barreales, Argentina. Ameghiniana $45,233-239$.

Pedersen, K.R., Friis, E.M, Crane, P.R., Drinnan, A.N., 1994. Reproductive structures of an extinct platanoid from the early Cretaceous (latest Albian) of eastern North America. Review of Palaeobotany and Palynology 80(3-4), 291-303. 
Petrulevicius, J.F., Nel, A., Sallenave, S., 2010. Recent genus Notonecta (Insecta: Heteroptera: Notonectidae) in the Lower Cretaceous of San Luis, Argentina: Palaeoecological implications. Annales de la Société entomologique de France (N.S.): International Journal of Entomology 46, 1-2.

Prámparo, M.B., 1988a. Esporas triletes levigadas y apiculadas de la Formación La Cantera (Cretácico de la Cuenca de San Luis) en su localidad tipo.IV Congreso Argentino de Paleontología y Bioestratigrafía, Actas III, 51-62. (Mendoza)

Prámparo, M.B., 1988b. Nuevos aportes a la palinología de la Formación La Cantera, Cretácico de la Cuenca de San Luis, en su localidad tipo. $4^{\circ}$ Congreso Argentino de Paleontología y Bioestratigrafía III, 41-50 (Mendoza, Argentina).

Prámparo, M.B., 1989. (Unpublished.) Palinología estratigráfica del Cretácico de la Cuenca de San Luis. Tesis Doctoral. Universidad Nacional de Río Cuarto, Córdoba.

Prámparo, M.B., 1990. Palynoestratigraphy of the Lower Cretaceous of the San Luis Basin, Argentina. Its place in the Lower Cretaceous floral provinces pattern. Neues Jahrbuchfür Geologie und Paläontologie Abhadlungen 18, 255-266.

Prámparo, M.B., 1994. Lower Cretaceous palynoflora of the La Cantera Formation, San Luis Basin. Correlation with other Cretaceous palynofloras of Argentina. Cretaceous Research 15, 193-203.

Prámparo, M.B., 1999a. Microfitoplancton orgánico del Cretácico Inferior de la Cuenca de San Luis. Parte I: Scenedesmaceae y Chlorococcaceae. Asociación Paleontológica Argentina. Publicación Especial 6. $10^{\circ}$ Simposio Argentino de Paleobotánica y Palinología 39-42 (Buenos Aires, Argentina).

Prámparo, M.B., 1999b. Granos de polen de primitivas angiospermas en el Cretácico Inferior de la Cuenca de San Luis y su distribución en otras cuencas cretácicas de Argentina. Boletim $5^{\circ}$ Simposio sobre o Cretaceo do Brasil, 539-543. (Brasil).

Prámparo, M.B., 2012. Non-marine Cretaceous palynomorph biostratigraphy of Argentina: a brief summary. Journal of Stratigraphy 36, 213-228.

Prámparo, M.B., Quattrocchio, M.E., Gandolfo, M.A., Zamaloa, M.C., Romero, E., 2007. Historia evolutiva de las angiospermas (Cretácico Paleógeno) en Argentina a través de los registros paleoflorísticos. Ameghiniana, Suplemento $50^{\circ}$ Aniversario, 157-172.

Prámparo, M.B., Vento, B., Narvaez, P., Mego, N., Puebla, G.G., 2018. Cretaceous climatic reconstruction from Argentina based on palynological data. Tomo Especial Paleoclimas en Iberoamerica. Boletin Geológico y Minero 129(4), 615-631.

Puebla, G.G., 2009. A new angiosperm leaf morphotype from the Early Cretaceous (Late Aptian) of San Luis basin, Argentina. Ameghiniana 46(3), 557-566.

Puebla, G.G., 2010 (unpubl.). Evolución de las comunidades vegetales basada en el estudio de la flora fósil presente en la Formación de La Cantera, Cretácico temprano, Cuenca de San Luis. Tesis Doctoral. PROBIOL. Universidad Nacional de Cuyo. Mendoza.

Puebla, G.G, Mego, N., Prámparo, M.B., 2012. Asociación de briófitas de la Formación La Cantera, Aptianotardio, Cuenca de San Luis, Argentina. Ameghiniana 49, 217-229.

Puebla, G.G., Iglesias, A., Gómez, M.A., Prámparo, M.B., 2017. Fossil record of Ephedra in the Lower Cretaceous (Aptian), Argentina. Journal of Plant Research 130(6), 975-988.

Quattrocchio, M.E., Volkheimer, W., Borrromei, A.M., Martinez, M.A., 2011. Changes of the palynobiotas in the Mesozoic and Cenozoic of Patagonia: a review. Biological Journal of the Linnean Society 103(2), 380-396.

Renzaglia, K.S., Schuette, S., Duff, R.J., Ligrone, R., Shaw, A.J., Mishler, B.D., Duckett, J.G., 2007. Bryophyte phylogeny: advancing the molecular and morphological frontiers. Bryologist 110, 179-213.

Rivarola, D., Spalletti, L., 2006. Modelo de sedimentación continental para el rift Cretácico de la Argentina central. Ejemplo de la Sierra de las Quijadas, San Luis. Revista de la Asociación Geológica Argentina 61, 63-80.

Rothwell, G.W., Stockey, R.A., Mapes, G., Hilton, J., 2011. Structure and relationships of the Jurassic conifer seed cone Hughmillerites juddii gen. et comb. nov.: implications for the origin and evolution of Cupressaceae. Review of Palaeobotany and Palynology 164(1), 45-59.

Rydin, C., Mohr, B., Friis, E.M., 2003. Cratonia cotyledon gen.et sp.nov., A unique Cretaceous Seedling related to Welwitschia. Proceedings; Biological Sciences, Supplement: Biology Letters, 29-32.

Rydin, C., Pedersen, K.R., Crane, P.R., Friis, E.M., 2006. Former diversity of Ephedra (Gnetales): Evidence from Early Cretaceous seeds from Portugal and North America. Annals of Botany 98, 123-140.

Salisbury, E.J., 1942. The reproductive capacity of plants. G. Bell and Sons, LTD. London.

Scotese, C.R., Boucot, A.J., McKerrow, W.S., 1999. Gondwanan palaeogeography and paleoclimatology. Journal of African Earth Sciences 28(1), 99-114.

Sha, J., 2007. Cretaceous stratigraphy of northeast China: non-marine and marine correlation. Cretaceous Research 28(2), 146-170.

Shipley, B., Dion, J., 1992. The allometry of seed production in herbaceous angiosperms. The American Naturalist 139(3), 467-483.

Silvertown, J.W., 1981. Seed size, life span, and germination date as co-adapted features of plant life history. American Naturalist 118, 860-864.

Sims, H.J., 2012. The evolutionary diversification of seed size: using the past to understand the present. Evolution 66(5), 1636-1649.

Skog, J.E., 2001. Biogeography of Mesozoic leptosporangiate ferns related to extant ferns. Brittonia 53(2), 236-269. 
Souza, J.M., Iannuzzi, R., 2012. Dispersal Syndromes of fossil Seeds from the Lower Permian of Paraná Basin, Rio Grande do Sul, Brazil. Anais da Academia Brasileira de Ciências 84(1), 43-68.

Spencer, A.R., Mapes, G., Bateman, R.M., Hilton, J., Rothwell, G.W., 2015. Middle Jurassic evidence for the origin of Cupressaceae: a paleobotanical context for the roles of regulatory genetics and development in the evolution of conifer seed cones. American Journal of Botany 102(6), 942-961.

Stevenson, R.A., Evangelista, D., Looy, C.V., 2015. When conifers took flight: a biomechanical evaluation of an imperfect evolutionary takeoff. Paleobiology 41(2), 205-225.

Stockey, R.A., Kvaček, J., Hill, R.S., Rothwell, G.W., Kvaček, Z., 2005. The fossil record of Cupressaceae s. lat. A monograph of Cupressaceae and Sciadopitys 54 , p. 68 .

Sun, G., Dilcher, D.L., 2002. Early angiosperms from the Lower Cretaceous of Jixi, eastern Heilongjiang, China. Review of Palaeobotany and Palynology 121(2), 91-112.

Sun, G., Dilcher, D.L., Zheng, S., Zhou, Z., 1998. In search of the first flower: a Jurassic angiosperm, Archaefructus, from northeast China. Science 282 (5394), 1692-1695.

Taylor, T.W., Hickey, L.J., 1990. An Attached leaves and lowers: implications origin. Science 247, 702-704.

Taylor, E.L., Taylor, T.N., Krings, M., 2009. Paleobotany: the biology and evolution of fossil plants. $2^{\circ}$ Edition. Academic Press, New York, USA.

Thomas, B.A., Spicer, R.A., 1986. The Evolution and Palaeobiology of Land Plants: Croom Helm, London.

Tiffney, B.H., 1984. Seed size, dispersal syndromes, and the rise of the angiosperms: evidence and hypothesis. Annals of the Missouri Botanical Garden 71, 551-576.

Tiffney, B.H., 2004. Vertebrate dispersal of seed plants through time. Annual Review of Ecology, Evolution and Systematics 35, 1-29.

Tosolini, A.M.P., McLoughlin, S., Wagstaff, B.E., Cantrill, D.J., Gallagher, S.J., 2015. Cheirolepidiacean foliage and pollen from Cretaceous highlatitudes of southeastern Australia. Gondwana Research 27(3), 960-977.

Traverse, A., 1988. Plant evolution dances to a different beat: plant and animal evolutionary mechanisms compared. Historical Biology 1(4), 277-301.

Vakhrameev, V.A., 1991 Jurassic and Cretaceous Floras and Climates of the Earth. Cambridge University Press, Cambridge.

Vanderpoorten, A., Goffinet, B., 2009. Introduction to bryophytes. Cambridge University Press.
Van Konijnenburg-Van Cittert, J.H.A., 2002. Ecology of some late Triassic to early Cretaceous ferns in Eurasia. Review of Palaeobotany and Palynology 119(1-2), 113-124.

Vaughan, J.G., 1970. The structure and utilization of oil seeds. Champan and Hall, London.

Villar De Seoane, L., Archangelsky, S., 2014. Estudios palinológicos del Grupo Baqueró (Cretácico Inferior), provincia de Santa Cruz, Argentina. X. Polen de Gymnospermae y Apéndice Final. Revista del Museo Argentino de Ciencias Naturales nueva serie 16(1), 33-44.

Wang, Q., 2011. Proposal to conserve the name Carpolithus with that spelling (fossil Spermatopsida). Taxon 60(1), 241-242.

Wang, X., Zheng, S., 2010. Whole fossil plants of Ephe$d r a$ and their implications on the morphology, ecology and evolution of Ephedraceae (Gnetales). Chinese Science Bulletin 55(15), 1511-1519.

Wang, Y., Olsen, P.E., Sha, J., Yao, X., Liao, H., Pan, Y., Kinney, S., Zhang, X., Rao, X., 2016. Stratigraphy, correlation, depositional environments, and cyclicity of the Early Cretaceous Yixian and Jurassic-Cretaceous Tuchengzi formations in the Sihetun area (NE China) based on three continuous cores. Palaeogeography, Palaeoclimatology, Palaeoecology 464, 110-133.

Westoby, M., Leishman, M., Lord, J., 1996. Comparative ecology of seed size and dispersal. Philosophical Transactions of the Royal Society of London. Series B: Biological Sciences 351(1345), 1309-1318.

Westoby, M., Falster, D.S., Moles, A.T., Vesk, P.A., Wright, I.J., 2002. Plant ecological strategies: some leading dimensions of variation between species. Annual Review of Ecology and Systematics 33(1), 125-159.

Wing, S.L., Tiffney, B.H., 1987. The reciprocal interaction of angiosperm evolution and tetrapod herbivory. Review of Palaeobotany and Palynology 50(1-2), 179-210.

Wing, S.L., Boucher, L.D., 1998. Ecological aspects of the Cretaceous flowering plant radiation. Annual Review of Earth and Planetary Sciences 26(1), 379-421.

Wu, M., Zhang, W., Guo, P., Zhao, Z., 2014. Identification of seven Zingiberaceous species based on comparative anatomy of microscopic characteristics of seeds. Chinese Medicine 9(10), 1-7.

Yang, Y., 2011. Cuticular Diversity of the Seed Outer Envelope in Ephedra (Ephedraceae) with A Discussion on Its Systematic Significance. Journal of Tropical and Subtropical Botany 19(1), 1-15.

Zander, A., 1979. The psychology of group processes. Annual Review of Psychology 30, 417-451. 